\title{
Montelukast moderately decreased asthma symptoms in children with persistent asthma
}

Knorr B, Franchi LM, Bisgaard H, et al. Montelukast, a leukotriene receptor antagonist, for the treatment of persistent

asthma in children aged 2 to 5 years. Pediatrics 2001 Sep;108:e48.

\section{QUESTION: In children with persistent asthma, is montelukast a well tolerated and effective therapeutic option?}

\section{Design}

Randomised \{allocation concealed*\} $\uparrow$, blinded (patients, clinicians, and \{data collectors $\} \uparrow$ ), ${ }^{*}$ placebo controlled trial with 12 weeks of follow up.

\section{Setting}

93 centres in Africa, Australia, Europe, North America, and South America.

\section{Patients}

689 children who were 2 to 5 years of age (mean age $4 y$, $59 \%$ boys, $56 \%$ white), had $\geqslant 3$ episodes of asthma symptoms in the previous year, had a total asthma symptom score $\geqslant 1$ (of 24 ) for $\geqslant 8$ days during the 2 week placebo baseline period, and used $\beta$ agonists for $\geqslant 8$ days during the placebo baseline period. Exclusion criteria included asthma intubation and emergency department treatment or admission to hospital for asthma within 1 month before the study. Follow up ranged from $98 \%$ to $100 \%$ for safety and from $81 \%$ to $96 \%$ for other outcomes.

\section{Intervention}

Patients were allocated to montelukast, $4 \mathrm{mg}$ chewable tablet $(n=461)$, or to placebo tablet $(n=228)$. Tablets were given once daily at bedtime for 12 weeks.

\section{Main outcome measures}

Safety, asthma symptoms, and days with $\beta$ agonist use and without asthma.

\section{Main results}

Analysis was by intention to treat for $\{$ safety $\} \nmid$ and effectiveness end points. The montelukast and placebo groups did not differ for frequency of overall adverse effects or individual adverse effects except for asthma, which occurred more frequently in the placebo group (30\% v 38\%, difference $8.0 \%, 95 \%$ CI 0.18 to 16 ). The groups did not differ for discontinuation of treatment because of adverse effects $(3.5 \%$ v $3.1 \%\{\mathrm{p}=0.999\}$ \$). Groups did not differ for $\geqslant 1$ laboratory adverse effect (3.6\% v 5.4\% $\{\mathrm{p}=0.31\}$ ). Montelukast decreased asthma symptom scores (table) and days with $\beta$ agonist use (49\% ข $55 \%, \mathrm{p}=0.001)$, and increased days without asthma $(34 \% v 28 \%, \mathrm{p}=0.002)$ more than did placebo.

\section{Conclusion}

In children with persistent asthma, montelukast was well tolerated, decreased asthma symptom scores and $\beta$ agonist use, and increased days without asthma.

*See glossary.

†nformation provided by author.

$\neq \mathrm{p}$ Values provided by author.
Montelukast v placebo at 12 weeks in children with persistent asthma

\begin{tabular}{|c|c|c|c|}
\hline \multirow[b]{2}{*}{ Outcomes§ } & \multicolumn{2}{|c|}{$\begin{array}{l}\text { Mean decrease in score from } \\
\text { baseline }\end{array}$} & \multirow{2}{*}{$\begin{array}{l}\text { Least-square mean } \\
\text { difference }(\mathrm{Cl})\end{array}$} \\
\hline & Montelukast & Placebo & \\
\hline $\begin{array}{l}\text { Overall daytime asthma } \\
\text { symptom score }\end{array}$ & 0.37 & 0.26 & $0.12(0.04$ to 0.20$)$ \\
\hline $\begin{array}{l}\text { Overnight asthma } \\
\text { symptom score }\end{array}$ & 0.46 & 0.37 & 0.11 (0.01 to 0.21$)$ \\
\hline
\end{tabular}

$\S$ No symptoms $=0$; severe symptoms $=4$ or 5 .

\section{COMMENTARY}

The well conducted multicentre study by Knorr $e t$ al showed that montelukast led to greater improvement in asthma symptoms and control than placebo. Because montelukast was compared with placebo, more studies are needed to clarify its effectiveness when compared or combined with other anti-inflammatory medications. One randomised controlled trial (RCT) in children showed that montelukast plus budesonide improved asthma control better than budesonide alone. ${ }^{1}$ Another RCT in adults also showed a treatment benefit after 16 weeks of beclomethasone plus montelukast. $^{2}$

For safety, caution is always needed when using tablets in young children. The American Academy of Pediatrics notes that safe swallowing can be difficult for young children for reasons of anatomy, experience, and judgment. ${ }^{3}$ However, many chewable tablets are approved for use in children $\geqslant 2$ years of age. ${ }^{4}$ The study by Knorr $e t$ al had a $90 \%$ probability of detecting an adverse drug reaction (ADR) of $7.8 \%$ in the montelukast group and $1 \%$ in the placebo group. However, the likelihood of detecting a less common ADR would be about $5 \%$ for an event occurring in 1 in 10000 patients. ${ }^{5}$ Thus, rare ADRs can only be determined by post-marketing surveillance.

What are the clinical implications? The National Asthma Education and Prevention programme expert panel has recommended leukotriene modifiers for persistent asthma in children $>5$ years of age. ${ }^{6}$ The study by Knorr $e t$ al now adds evidence for its effectiveness in younger children.

Lynnette J Mazur, MD, MPH University of Texas-Houston Health Science Center Houston, Texas, USA

1 Simons FE, Villa JR, Lee BW, et al. Montelukast added to budesonide in children with persistent asthma: a randomized, double-blind, crossover study. J Pediatr 2001;138:694-8.

2 Laviolette M, Malmstrom K, Lu S, et al. Montelukast added to inhaled beclomethasone in treatment of asthma. Montelukast/Beclomethasone Additivity Group. Am JRespir Crit Care Med 1999;160:1862-8.

3 Widome MD, editor. Injury prevention and control for children and youth. 3rd edition. Elk Grove Village, IL: The Academy, 1997.

4 Michele TM, Knorr B, Vadas EB, et al. Safety of chewable tablets in children.J Asthma 2002 (in press).

5 Hanley JA, Lippman-Hand A. If nothing goes wrong, is everything all right? Interpreting zero numerators. JAMA 1983;249:1743-5.

6 Guidelines for the diagnosis and management of asthma: expert panel report 2. Bethesda, MD: National Heart, Lung, and Blood Institute, 1997 (http://www.nhlbi.nih.gov/guidelines/ asthma/asthgdln.pdf). 